phase was suspected.

Nevertheless, the indications are strong that grain boundaries can have a striking effect on the steady-state erosion rate. This result could have practical importance in that an optimum microstructure could be produced which would result in a maximum erosion resistance for a given set of erosion conditions. The effect of grain boundaries on erosion should be studied further.

${ }^{1}$ J. L. Routbort, R. O. Scattergood, and A. P. L. Turner, "The Erosion of Reaction-Bonded SiC, "Wear, 59, 363-75 (1980).

2J. L. Routbort and R. O. Scattergood, "Erosion of Silicon Single Crystals": to be published in the Journal of the American Ceramic Society.

${ }^{3}$ M. E. Gulden; pp. 101-21 in Erosion: Prevention and Useful Applications. Edited by W. F. Adler. Am. Soc. Test Mater., Spec. Tech. Publ., 1979, No. 664

${ }^{4}$ A. G. Evans, M. E. Gulden, and M. Rosenblatt, "Impact Damage in Brittle Materials in the Elastic-Plastic Response Regime," Proc. R. Soc. London, Ser. A, 361, 343-65 (1978).

5S. M. Wiederhorn and B. R. Lawn, "Strength Degradation of Glass Impacted with Sharp Particles: I,"J Am. Ceram. Soc., 62 [1-2] 66-70 (1979).

\section{Subsolidus Phase Equilibria in the System $\mathrm{ZrO}_{2}-\mathrm{Y}_{2} \mathrm{O}_{3}-\mathrm{Al}_{2} \mathrm{O}_{3}$}

\section{W. D. TUOHIG* and T. Y. TIEN*}

CUBic $\mathrm{ZrO}_{2}$ is presently used as the electrolyte in the automotive exhaust gas sensor which provides the feedback signal for closedloop control of the air-fuel mixture supplied to the engine.$^{1-5}$ The present work was undertaken as part of an effort to optimize the $\mathrm{Y}_{2} \mathrm{O}_{3}$-stabilized $\mathrm{ZrO}_{2}$ ceramic electrolyte. Yttria $\left(\mathrm{Y}_{2} \mathrm{O}_{3}\right)$ is the preferred stabilizer for sensor applications, despite its high cost, because it produces an electrolyte with both higher conductivity and greater stability. ${ }^{6-8}$ Aluminum oxide $\left(\mathrm{Al}_{2} \mathrm{O}_{3}\right)$ is added to the body to promote densification and reduce the required firing temperature. ${ }^{9}$

Binary equilibria in the system $\mathrm{ZrO}_{2}-\mathrm{Y}_{2} \mathrm{O}_{3}-\mathrm{Al}_{2} \mathrm{O}_{3}$ are reasonably well established. However, no information appears to be available for the ternary system. The system $\mathrm{Al}_{2} \mathrm{O}_{3}-\mathrm{ZrO}_{2}$, the least complex of the binaries, contains only a eutectic at $1870^{\circ} \mathrm{C}$ between the constituent oxides ${ }^{10}$ The phase diagram for the system $\mathrm{Al}_{2} \mathrm{O}_{3}-\mathrm{Y}_{2} \mathrm{O}_{3}$ was

Presented at the 81 st Annual Meeting, The American Ceramic Society, Cincinnati, Ohio, May 2, 1979 (Basic Science Division No. 116-B-79). Received March 27, 1980; revised copy received April 15, 1980

W. D. Tuohig is with the Bendix Advanced Technology Center, Southfield, Michigan 48037. T. Y. Tien is with the University of Michigan, Ann Arbor, Michigan 48104 .

"Member, the American Ceramic Society. first proposed by Olds and Otto, $"$ but did not include the 1:1 compound $\mathrm{AlYO}_{3}$. Although the existence of $\mathrm{AlYO}_{3}$ has been reported by Roth ${ }^{12}$ and by Keith and Roy, ${ }^{13}$ the stability limits have not been conclusively established. A $2: 1$ compound $\left(2 \mathrm{Y}_{2} \mathrm{O}_{3} \cdot \mathrm{Al}_{2} \mathrm{O}_{3}\right)$ decomposes to yield garnet $\left(3 \mathrm{Y}_{2} \mathrm{O}_{3} \cdot 5 \mathrm{Al}_{2} \mathrm{O}_{3}\right)$ and cubic $\mathrm{Y}_{2} \mathrm{O}_{3}$ at low temperatures. ${ }^{14}$

A diagram of the system $\mathrm{ZrO}_{2}-\mathrm{Y}_{2} \mathrm{O}_{3}$, published by Stubican $e t$ al.,$^{15}$ is similar to one reported by Srivastava et al.$^{16}$ at $>1400^{\circ} \mathrm{C}$. Decreasing stability limits with decreasing temperature for the cubic $\mathrm{ZrO}_{2}$ phase and the existence of a cubic allotrope of pure $\mathrm{ZrO}_{2}$ at high temperatures are significant features of these diagrams.

Specimens for the present study were prepared by mixing appropriate quantities of oxide powders (Table 1) to produce batches $(\approx 50 \mathrm{~g}$ ) of material. The powders were ground in a mortar and pestle as an acetone slurry and calcined for $10 \mathrm{~h}$ at $1250^{\circ} \mathrm{C}$. The resulting cakes were then crushed and pressed in a hardened steel die using a stearic acid lubricant. Compositions (Table II) were selected to distinguish clearly the valid joins in the system. The subsolidus was determined by exploratory firings at $30^{\circ} \mathrm{C}$ intervals between $1450^{\circ}$ and $1600^{\circ} \mathrm{C}$. Ceramographic specimens were then examined by scanning electron microscopy (SEM) for evidence of liquation. Two firing schedules were used: (1) isothermal firing at $1450^{\circ} \pm 10^{\circ} \mathrm{C}$ for $500 \mathrm{~h}$ and (2) firing for $20 \mathrm{~h}$ at $1650^{\circ}$ followed by equilibration at $1450^{\circ} \mathrm{C}$ for $300 \mathrm{~h}$. Pellets were cooled at $\approx 80^{\circ} \mathrm{C} /$ min from $1450^{\circ} \mathrm{C}$.

The fired pellets were crushed and ground for $\mathrm{X}$-ray analysis in an $\mathrm{Al}_{2} \mathrm{O}_{3}$ mortar and pestle. (No $\mathrm{Al}_{2} \mathrm{O}_{3}$ lines could be detected in trial samples prepared without $\mathrm{Al}_{2} \mathrm{O}_{3}$ additions.) $\mathrm{X}$-ray analysis was conducted using a standard diffractometer, ${ }^{*} \mathrm{CuK} \alpha$ radiation, $1 / 2^{\circ}$ slits, and a graphite monochrometer. Precision lattice parameters for the $\mathrm{ZrO}_{2}$ solid solutions were obtained using the diffractometer operated at $1 / 2 \%$ min with silicon as a standard. A Nelson-Riley extrapolation function ${ }^{17}$ was used to calculate $a_{0}$ values. Sibling samples were prepared for SEM examination using standard ceramographic procedures.

Results of the X-ray analysis are given in Table II. Patterns

*Norelco, North American Philips Corp., New York, N.Y.

Table I. Oxide Powders Used to Prepare Compositions

\begin{tabular}{ccc} 
Oxide & $\begin{array}{c}\text { Nominal } \\
\text { purity }(\%)\end{array}$ & $\begin{array}{c}\text { Particle } \\
\text { size }(\mu \mathrm{m})\end{array}$ \\
\hline $\mathrm{ZrO}_{2}{ }^{*}$ & 98.6 & 2.8 \\
& $(\mathrm{Zr}+\mathrm{H})$ & \\
& 99.99 & 10 \\
$\mathrm{Y}_{2} \mathrm{O}_{3}{ }^{\dagger}$ & $99+$ & 0.3 \\
$\mathrm{Al}_{2} \mathrm{O}_{3}{ }^{\dagger}$ & 9
\end{tabular}

*Zircoa A, Zircoa Products, Coming Glass Works, Solon, Ohio. †Code 99.99 Molybdenum Corporation of America, White Plains, N.Y. $\ddagger$ Linde A, Union Carbide Corp., New York, N.Y.

Table II. X-Ray Results

\begin{tabular}{|c|c|c|c|c|c|c|c|c|c|c|c|}
\hline \multirow{2}{*}{$\begin{array}{c}\text { Composition } \\
\text { No. }\end{array}$} & \multicolumn{3}{|c|}{ Composition (mol\%) } & \multicolumn{7}{|c|}{ Phases identified ${ }^{*}$} & \multirow{2}{*}{$\begin{array}{c}\text { Cubic } \mathrm{ZrO}_{2} \\
\text { lattice parameter, } \\
a_{0}(\mathrm{~nm} \times 10)\end{array}$} \\
\hline & $\mathrm{ZrO}_{2}$ & $\mathrm{Y}_{2} \mathrm{O}_{3}$ & $\mathrm{Al}_{2} \mathrm{O}_{3}$ & $\bar{C}$ & $\overline{\mathbf{M}}$ & A & $\mathrm{Y}$ & YAG & YA & $\mathrm{Y}_{2} \mathrm{~A}$ & \\
\hline 1 & 90 & 5 & 5 & $\mathrm{X}$ & $\mathrm{X}$ & $\mathrm{X}$ & & & & & 5.12 \\
\hline 2 & 84 & 8 & 8 & $\mathrm{X}$ & & $\mathrm{X}$ & & & & & 5.14 \\
\hline 3 & 80 & 10 & 10 & $\mathrm{X}$ & & $\mathrm{X}$ & & & & & 5.14 \\
\hline 4 & 76 & 12 & 12 & $\mathrm{X}$ & & $\mathrm{X}$ & & $\mathrm{X}$ & & & 5.15 \\
\hline 5 & 73 & 17 & 10 & $\mathrm{X}$ & & $\mathrm{X}$ & & $\mathrm{X}$ & & & \\
\hline 6 & 65 & 25 & 10 & $\mathrm{X}$ & & & & $\mathrm{X}$ & & & 5.17 \\
\hline 7 & 53 & 32 & 15 & $\mathrm{X}$ & & & & $\mathrm{X}$ & & & 5.24 \\
\hline 8 & 40 & 40 & 20 & $\mathrm{X}$ & & & & $\mathrm{X}$ & $X$ & $\mathrm{X}$ & 5.24 \\
\hline 9 & 35 & 10 & 55 & $\mathrm{X}$ & & $\mathrm{X}$ & & $\mathrm{X}$ & & & 5.15 \\
\hline 10 & 25 & 50 & 25 & $\mathrm{X}$ & & $\mathrm{X}$ & & & $\mathrm{X}$ & $\mathrm{X}$ & 5.24 \\
\hline 11 & 20 & 60 & 20 & $\mathrm{X}$ & & & $\mathrm{X}$ & & & $X$ & 5.24 \\
\hline 12 & 15 & 70 & 15 & $\mathrm{X}$ & & & $\mathrm{X}$ & & & $\mathrm{X}$ & \\
\hline 13 & 0 & 67 & 33 & & & & $\mathrm{X}$ & & $\mathrm{X}$ & $\mathrm{X}$ & \\
\hline
\end{tabular}

${ }^{*} \mathrm{C}=$ cubic $\mathrm{ZrO}_{2}, \mathrm{M}=$ monoclinic $\mathrm{ZrO}_{2}$ (implies tetragonal $\mathrm{ZrO}_{2}$ at $1450^{\circ} \mathrm{C}$ ), $\mathrm{A}=\mathrm{Al}_{2} \mathrm{O}_{3}$ (corundum), $\mathrm{Y}=\mathrm{Y}_{2} \mathrm{O}_{3}$ (cubic), $\mathrm{YAG}=3 \mathrm{Y}_{2} \mathrm{O}_{3}-5 \mathrm{Al}_{2} \mathrm{O}_{3}$ (garnet), $\mathrm{YA}=\mathrm{AlYO}_{3}$, and $\mathrm{Y}_{2} \mathrm{~A}=2 \mathrm{Y}_{2} \mathrm{O}_{3} \cdot \mathrm{Al}_{2} \mathrm{O}_{3}$ 


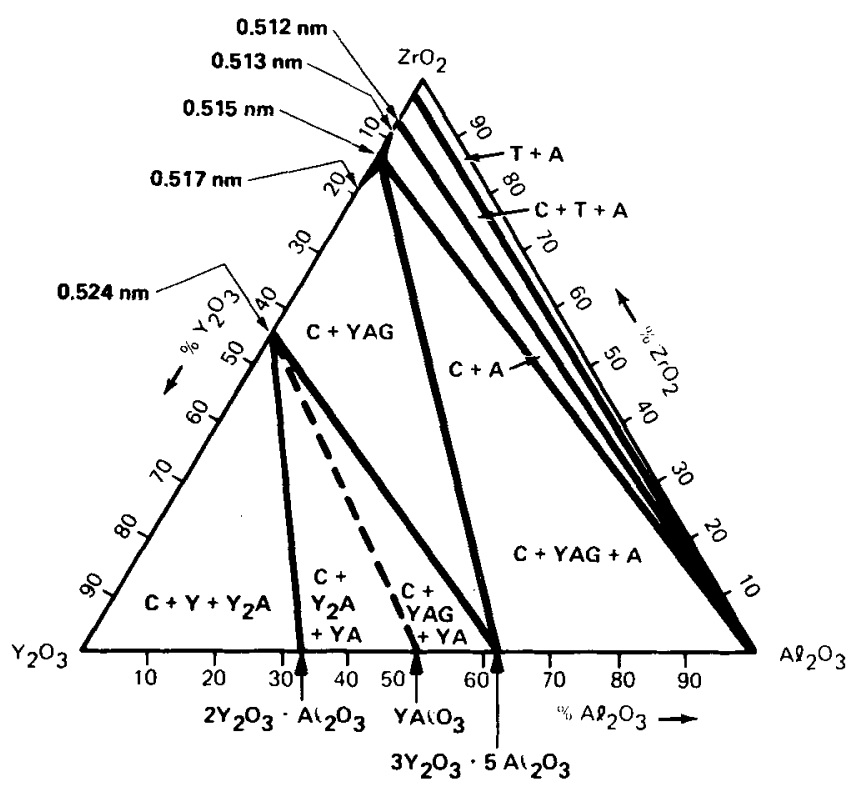

Fig. 1. Subsolidus phase equilibria in the system $\mathrm{ZrO}_{2}-\mathrm{Y}_{2} \mathrm{O}_{3}-\mathrm{Al}_{2} \mathrm{O}_{3}$.

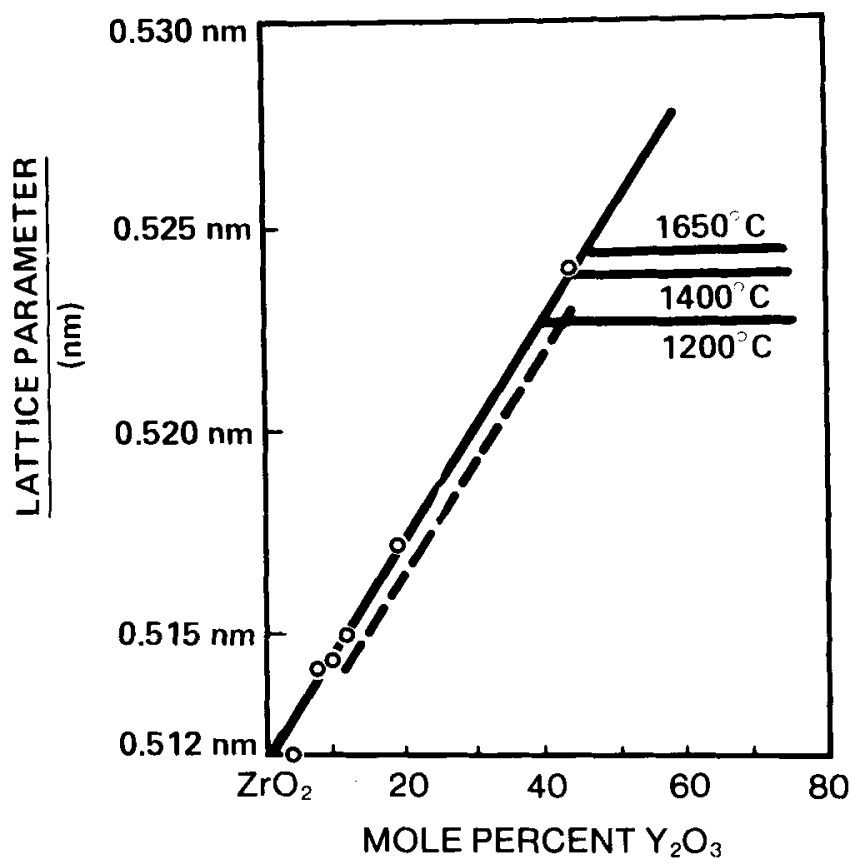

Fig. 2. Solid-solution lattice parameters vs mol\% $\mathrm{Y}_{2} \mathrm{O}_{3}$; solid line from Ref. 15, dashed line from Ref. 8.

obtained from specimens fired isothermally at $1450^{\circ} \mathrm{C}$ and those fired using the $1650^{\circ} / 1450^{\circ} \mathrm{C}$ schedule were in agreement. However, patterns from the latter series were used to determine lattice parameters because of better line definition.

The ternary subsolidus phase relations are shown in Fig. 1. Two regions of two-phase equilibria (cubic $\mathrm{ZrO}_{2}+\mathrm{Al}_{2} \mathrm{O}_{3}$ and cubic $\mathrm{ZrO}_{2}+3 \mathrm{Y}_{2} \mathrm{O}_{3} \cdot 5 \mathrm{Al}_{2} \mathrm{O}_{3}$ ) were observed. No change in lattice parameter with composition was noted for $\mathrm{Al}_{2} \mathrm{O}_{3}$ or $3 \mathrm{Y}_{2} \mathrm{O}_{3} \cdot 5 \mathrm{Al}_{2} \mathrm{O}_{3}$. Consequently, it was assumed that solubility of cubic $\mathrm{ZrO}_{2}$ in either phase was negligible; tie lines could then be drawn from these endmembers through the sample compositions to the $\mathrm{ZrO}_{2}-\mathrm{Y}_{2} \mathrm{O}_{3}$ binary side of the diagram.
The lattice parameters of the cubic solid solutions (Table II) are plotted as a function of the compositions predicted by the tie lines in Fig. 2. The data of Stubican $e t$ al..$^{15}$ and of Strickler and Carlson ${ }^{8}$ are included in the figure for comparison. A constant value of the $\mathrm{ZrO}_{2}$ lattice parameter $(0.515 \mathrm{~nm})$ was observed for compositions in the $\mathrm{ZrO}_{2}+$ garnet + corundum three-phase field. On the basis of Fig. 2, the apex of the compatibility triangle was located at $\approx 12 \mathrm{~mol} \%$ $\mathrm{Y}_{2} \mathrm{O}_{3}$.

Microstructural observations by SEM were consistent with the $\mathrm{X}$-ray diffraction data. Nondispersive $\mathrm{X}$-ray analyses of the phases present in both the cubic $\mathrm{ZrO}_{2}+\mathrm{Al}_{2} \mathrm{O}_{3}$ region and the cubic $\mathrm{ZrO}_{2}+\mathrm{Al}_{2} \mathrm{O}_{3}+3 \mathrm{Y}_{2} \mathrm{O}_{3} \cdot 5 \mathrm{Al}_{2} \mathrm{O}_{3}$ phase field substantiate $\mathrm{ZrO}_{2}$ solid solubility below the limits of detection.

${ }^{1}$ D. S. Eddy, "Physical Principles of the Zirconia Exhaust Gas Sensor," IEEE Trans. Veh. Technol., VT-23 [4] 125-28 (1974)

${ }^{2} \mathrm{E}$. Hamann, H. Manger, and L. Steinke, "Lambda-Sensor with $\mathrm{Y}_{2} \mathrm{O}_{3}$ Stabilized $\mathrm{ZrO}_{2}$ Ceramic for Application in Automotive Emission Control System,"' Tech. Pap SAE-770401, 1977;6 pp.

${ }^{3} \mathrm{H}$. Dueker, K. H. Friese, and W. D. Haecker, "Ceramic Aspects of the Bosch Lambda-Sensor," SAE Trans., 84, 807-24 (1975).

${ }^{4}$ W. J. Fleming, "Physical Principles Governing Nonideal Behavior of the Zirconia Oxygen Sensor," J. Electrochem. Soc., 124 [1] 21-28 (1977)

s"Lambda-Sond: Complete Emission Control?" Automob. Eng., 85 [2] 45-51 $(1977)$.

${ }^{6} \mathrm{R}$. V. Wilhelm, Jr. and D. S. Eddy, "MgO- $\mathrm{Y}_{2} \mathrm{O}_{3}$-Stabilized $\mathrm{ZrO}_{2}$ Ceramics in Exhaust Gas Sensor," Am. Ceram. Soc. Bull., 56 [5] 509-12 (1977).

${ }^{7} \mathrm{C}$. T. Young and J. D. Bode, "Characteristics of $\mathrm{ZrO}_{2}$-Type Oxygen Sensors for Automotive Applications," Tech. Pap. SAE-790143, 1977.

${ }^{8} \mathrm{D}$. W. Strickler and W. G. Carlson, "Ionic Conductivity of Cubic Solid Solutions in the System $\mathrm{CaO}-\mathrm{Y}_{2} \mathrm{O}_{3}-\mathrm{ZrO}_{2}$,"J.Am. Ceram. Soc., 47 [3] 122-27 (1964).

${ }^{9} B$. Topp, $H$. Neidhard, R.'Pollner, and K. H. Friese, "Method for Producing Oxygen Sensing Element, Particularly for Use with Internal Combustion Engine Exhaust Emission Analysis,' 'U.S. Pat. 3978 006, August 31, 1976.

${ }^{10}$ A. M. Alper; p. 339 in Science of Ceramics, Vol. 3. Edited by G. H. Stewart, Academic Press, New York, 1967.

${ }^{\prime \prime E}$. M. Levin, C. R. Robbins, and H. F. McMurdie, Phase Diagrams for Ce ramists. Edited by M. K. Reser. American Ceramic Society, Columbus, Ohio, 1964; Fig. 311 .

${ }^{12} \mathrm{R}$. S. Roth, "Classification of Perovskite and Other ABO ${ }_{3}$-Type Compounds, "J. Res. Natl. Bur. Stand., 58 [2] 75-88 (1957).

${ }_{13} \mathrm{M}$. L. Keith and R. Roy, "Structural Relations Among Double Oxides of Trivalent Elements," Am. Mineral., 39 [1-2] 1-23 (1954).

${ }^{14}$ S. J. Schneider, R. S. Roth, and J. L. Waring, "Solid-State Reactions Involving Oxides of Trivalent Cations, "J. Natl. Bur. Stand., Sect. A, 65 [4] 345-74 (1961). ${ }^{15} \mathrm{~V}$. S. Stubican, R. C. Hink, and S. P. Ray, "Phase Equilibria and Ordering in the System $\mathrm{ZrO}_{2}-\mathrm{Y}_{2} \mathrm{O}_{3}$," J. Am. Ceram. Soc., 61 [1-2] 17-21 (1978).

${ }^{16}$ K. K. Srivastava, R. N. Patil, C. B. Choudhary, K. V. G. K. Gokhale, and E. C. Subbarao, "Revised Phase Diagram of the System $\mathrm{ZrO}_{2}-\mathrm{YO}_{1.5}$, "Trans. J. Br. Ceram Soc., 73 [3] 85-91 (1974).

${ }^{1}$ B. D. Cullity, Elements of X-Ray Diffraction, 2d ed.; p. 356. Addison-Wesley, Reading, Mass., 1978.

\section{Monolithic Multilayer Electromechanical Transducers for Optical Applications}

\section{W. A. SCHULZE, T. R. SHROUT, S. J. JANG, S. SHARP, and} L. E. CROSS ${ }^{\star}$

LASER-COMMUNICATION and information-processing systems have increased the need for simple electrically controllable micropositioners. Several of these needs have been met by using conventional piezoceramic materials; however, these materials often need very high driving voltages to develop the required displacements. They also lead to zero point drift due to aging and deaging under repeated field cycling.

Integral noble metal electrodes can be used to reduce the high driving voltage requirements in conventional piezoceramics. To explore this possibility, multilayer elements were fabricated from a low-hysteresis commercial PZT by using normal tape casting techniques. ${ }^{1}$ The individual units consisted of 10 active layers

Received April 11, 1980; revised copy received May 23, 1980

The writers are with the Materials Research Laboratory, The Pennsylvania State University, University Park, Pennsylvania 16802.

"Member, the American Ceramic Society. 